\title{
Erratum: Prospective immune profiling in critically ill adults: before, during and after severe sepsis and septic shock
}

N. Layios ${ }^{1,2,3^{*}}$, C. Gosset ${ }^{4}$, C. Delierneux ${ }^{2}$, A. Hego ${ }^{2}$, J. Huart ${ }^{2}$, A. Joly ${ }^{5}$, P. Geurts ${ }^{5}$, P. Damas ${ }^{1}$, C. Oury² ${ }^{2+}$ and A. Gothot ${ }^{2,4+}$

\section{Erratum}

After publication of our recent Poster presentation [1], we noticed that C Gosset, C. Delierneux, A. Hego, J Huart, A Joly, P Geurts, P Damas, C Oury and A Gothot had been inadvertently omitted as co-authors. The author list is now complete and the competing interests section modified accordingly.

\section{Competing interests}

The authors declare that they have no competing interests.

\section{Author details}

'Department of General Intensive Care, University Hospital Centre of Liège, Domaine Sart-Tilman B35, Liège 4000, Belgium. ${ }^{2}$ GIGA-Cardiovascular Sciences, Laboratory of Thrombosis and Hemostasis, University of Liège, Domaine Sart-Tilman B35, 4000 Liège, Belgium. ${ }^{3} \mathrm{CHU}$ de Liège, Domaine Sart-Tilman B35, 4000 Liège, Belgium. ${ }^{4}$ Laboratory Hematology, University Hospital Centre of Liège, Liège, Belgium. ${ }^{5}$ Systems and Modeling

Department of Electrical Engineering and Computer Science and GIGA-R, University of Liège, Domaine Sart-Tilman B35, 4000 Liège, Belgium.

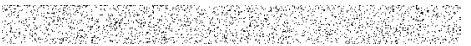

\section{Reference}

1. Layios N. Prospective immune profiling in critically ill adults: before, during and after severe sepsis and septic shock. Crit Care. 2015;19(Suppl 1):P43.

* Correspondence: nathalie.layios@chu.ulg.ac.be

${ }^{\dagger}$ Equal contributors

'Department of General Intensive Care, University Hospital Centre of Liège, Domaine Sart-Tilman B35, Liège 4000, Belgium

${ }^{2}$ GIGA-Cardiovascular Sciences, Laboratory of Thrombosis and Hemostasis,

University of Liège, Domaine Sart-Tilman B35, 4000 Liège, Belgium

Full list of author information is available at the end of the article

\section{Submit your next manuscript to BioMed Central} and take full advantage of:

- Convenient online submission

- Thorough peer review

- No space constraints or color figure charges

- Immediate publication on acceptance

- Inclusion in PubMed, CAS, Scopus and Google Scholar

- Research which is freely available for redistribution

Submit your manuscript at www.biomedcentral.com/submit
C) Biomed Central reproduction in any medium, provided you give appropriate credit to the original author(s) and the source, provide a link to the Creative Commons license, and indicate if changes were made. The Creative Commons Public Domain Dedication waiver (http://creativecommons.org/publicdomain/zero/1.0/) applies to the data made available in this article, unless otherwise stated. 